\title{
Density-dependent switches in diet: a likely mechanism for negative feedbacks on goose population increase?
}

\author{
Dries Pieter Jan Kuijper · R. Ubels • \\ M. J. J. E. Loonen
}

Received: 27 February 2009/Revised: 13 June 2009/ Accepted: 23 June 2009/Published online: 22 July 2009

(C) The Author(s) 2009. This article is published with open access at Springerlink.com

\begin{abstract}
Goose grazing on arctic tundra vegetation has shown both positive and negative effects on subsequent foraging conditions. To understand the potential of a density-dependent feedback on herbivore population size, the relation between grazing pressure and future foraging conditions is essential. We studied the effect of increasing grazing pressure of barnacle geese (Branta leucopsis) on Spitsbergen. During the establishment of a breeding colony in the period 1992-2004, the proportion of graminoids decreased in the diet of wild geese, while the percentage of mosses increased. Grazing trials with captive geese in an unexploited area showed a similar shift in diet composition. High-quality food plants were depleted within years and over years. Intake rate declined too and as consequence, metabolisable energy intake rate (MEIR) decreased rapidly with increasing grazing pressure. During three successive years of experimental grazing, MEIR decreased at all levels of grazing pressure and declined below minimal energetic requirements when grazing exceeded natural levels of grazing pressure. This suggests that foraging conditions rapidly decline with increasing grazing pressure in these low-productive habitats. The potential for
\end{abstract}

D. P. J. Kuijper · R. Ubels · M. J. J. E. Loonen

Arctic Centre, University of Groningen, P.O. Box 716, 9700 AS

Groningen, The Netherlands

D. P. J. Kuijper · R. Ubels

Animal Ecology Group, Center for Ecological and Evolutionary Studies, University of Groningen, P.O. Box 14, 9750 AA Haren,

The Netherlands

D. P. J. Kuijper $(\square)$

Mammal Research Institute, Polish Academy of Sciences, ul.

Waszkiewicza 1d, 17-230 Białowieża, Poland

e-mail: dkuijper@zbs.bialowieza.pl density-dependent feedbacks on local population increase is discussed.

Keywords Depletion - Grazing pressure · Habitat degradation · Branta leucopsis $\cdot$ Svalbard . Spitbergen

\section{Introduction}

Many arctic-breeding goose populations have increased substantially during the last decades, and are linked to improved foraging conditions in their wintering habitats (Jefferies et al. 2004; Fox et al. 2005). These increasing numbers have resulted in increased grazing pressure in many traditional breeding areas. Studies from these (sub-) arctic-breeding areas showed contrasting effects of increased grazing pressure on the vegetation, leading either to improved (Cargill and Jefferies 1984; Hik and Jefferies 1990; Person et al. 2003) or deteriorated foraging conditions (Zellmer et al. 1993; Gadallah and Jefferies 1995b; Jefferies and Rockwell 2002) with potential feedbacks on population growth.

In the short term, goose grazing may stimulate aboveground biomass production (Hik and Jefferies 1990). Studies from La Pérouse Bay showed that grazing and nutrient additions via faeces stimulated growth of graminoids and increased potential harvest and diet quality for geese (Cargill and Jefferies 1984; Bazely and Jefferies 1989; Hik and Jefferies 1990). These positive effects of goose grazing were observed at a population level lower than currently observed (Jefferies et al. 2004). Studies from other areas did not find over-compensation of aboveground production but did observe improved forage quality following grazing (Gauthier et al. 1995; Person et al. 1998). 
In the long term, continuous grazing can promote grazing lawns, consisting of vegetation dominated by a high density of grazing-tolerant plant species with high nutrient concentrations (McNaughton 1984). Person et al. (2003) found that the areal extent of grazing lawns increased with an increase in population size in breeding areas of black brant (Branta bernicla nigricans) in southwestern Alaska. This led to improved foraging conditions which resulted in higher growth rates of goslings. The authors suggested that these herbivore-mediated changes in the vegetation have led to a positive feedback on population growth rate.

In contrast, when consumption rate of herbivores exceeds growth rate of plants, grazing can lead to a rapid depletion of forage plants (Rowcliffe et al. 2001). Increasing grazing pressure will then lead to an increased rate of depletion (Vickery et al. 1995). Long-term effects of high grazing pressure may then result in vegetational changes leading to deteriorated foraging conditions for geese. Overexploitation of vegetation occurred at the (sub-) arctic-breeding areas of lesser snow geese (Anser caerulescens caerulescens) in La Pérouse Bay, Canada. The intense grazing and grubbing of increasing numbers of geese led to the loss of vegetation (Jefferies and Rockwell 2002) and erosion of the surface organic layer (Kotanen and Jefferies 1997). These processes have led to the establishment of an alternative stable state (exposed, unvegetated sediment) over large expanses of coastal marshes where geese stage or breed (Jefferies et al. 2006). The lack of preferred high-quality food plants in these areas has forced geese to switch to alternative lower quality forage plants that were less tolerant to grazing (Zellmer et al. 1993; Gadallah and Jefferies 1995a). These deteriorating foraging conditions resulted in a long-term decline in gosling size (Cooch et al. 1993) and adult reproductive output (Williams et al. 2005).

Understanding the mechanisms that explain these observed contrasting effects of increased goose grazing pressure on future foraging conditions is crucial to predict the possible feedback mechanisms on population growth for other arctic-breeding goose species. When increasing grazing pressure leads to depletion of preferred resources, herbivores are forced to switch to alternative foods or to move to areas with greater resource availability. As most geese demonstrate high fidelity to their breeding grounds and brood rearing areas (Cooch et al. 1993; Lindberg and Sedinger 1998), geese often switch to alternative foods. Both in areas where positive (Person et al. 2003) and negative feedbacks (Zellmer et al. 1993; Gadallah and Jefferies 1995b) were observed, diet switches occurred from depleted preferred to less preferred species. However, the vegetation and abiotic conditions responded differently to these shifts in grazing. In La Pérouse Bay, alternative food plants were less tolerant to grazing and increased grazing led to a rapid decrease of these species. Additionally, changed abiotic conditions prevented a recovery of the vegetation to its original state (Zellmer et al. 1993; Gadallah and Jefferies 1995b). In contrast, in southwestern Alaska, increased goose grazing on alternative food plants (Carex rameskii) led to a vegetation dominated by the preferred food plant (Carex subspathacea) and increased the areal extent of the preferred vegetation type (Person et al. 2003).

In the present study, we studied how intra- and interseasonal foraging conditions change in relation to increasing grazing pressure of barnacle geese (Branta leucopsis) breeding at Spitsbergen (Svalbard). This population has increased from less than 1,000 in 1948 to 25,750 in 2000 (Owen and Black 2005). Two approaches were used. First, diet composition was studied at different stages of population development in a growing breeding colony of barnacle geese in the period 1990-2004. Switches in diet composition could suggest changing foraging conditions as a result of increased goose grazing. Secondly, by means of grazing trails using captive geese, we established the relation between grazing pressure and diet composition in an area not exploited by geese to find out whether the observed diet changes indicate depletion of preferred food plants. To answer the question whether increased goose grazing leads to improved or deteriorated foraging conditions, we studied the energetic consequences of the observed diet changes. Based on chemical analyses of the selected food in combination with measured intake rate (IR), we calculated the energy IR and studied the relationship with goose grazing pressure. The results are discussed in the light of the predicted increase in goose numbers and possible feedback mechanisms.

\section{Materials and methods}

Changes in diet composition in a growing breeding colony

\section{Study site 1}

Since the early 1980s, a new barnacle goose colony established in the Kongsfjorden area near the village of Ny-Ålesund $\left(78.9^{\circ} \mathrm{N}, 11.9^{\circ} \mathrm{E}\right)$ at Spitsbergen, Svalbard (Loonen et al. 1998). The number of geese of this colony has increased from 196 adults in 1990 to 783 in 1997 (Loonen et al. 1998) reaching a maximum of ca. 900 adults in 1999 after which it has fluctuated between 800 and 450 adults (M.J.J.E. Loonen, unpublished data). The area inside and in close vicinity of Ny-Ålesund is intensively grazed. In spring, it is visited by families of barnacle geese and later in the season it is an important moulting area for 
families and non-breeders (Loonen et al. 1998). Due to the wet conditions and constant presence of people, reindeer grazing pressure is low in these areas (M.J.J.E. Loonen, unpublished data). Two main habitat types used by foraging geese can be distinguished in this area. Wet, mossdominated tundra is bordering small lakes (Solvatnet, Månevatnet) and the sea shore. The vegetation is dominated by moss (Calliergon richardsonii as the most abundant species) with vascular plant species such as Ranunculus hyperboreus and Saxifraga cernua with Poa arctica as the dominant graminoid. The second habitat, found at higher elevation, consists of dry to mesic tundra. Dominant graminoids are Deschampsia alpina and Carex spp. and to a lesser extent Poa arctica. A variety of dicots can be found such as Cerastium arcticum, Bistorta vivipara, Saxifraga cespitosa and Cardamine pratensis ssp. polemonioides with Sanionia uncinata and Tomenthypnum nitens as the most abundant moss species.

\section{Diet analyses}

Diet composition was determined on the basis of plant epidermal fragments. As geese show low digestive efficiency and epidermis fragments remain sufficiently intact to enable identification; this method can be used to reconstruct the diet from dropping contents (Owen 1975) and has been shown to precisely estimate diet composition in other herbivores (Alipayo et al. 1992). Goose dropping samples for diet analyses were collected in both the wet and mesic tundra areas in the vicinity of the village in 1990 (7-25 July), 1997 (19-22 July) and 2004 (15 July). In 1997 and 2004, samples were collected consisting of 5-6 droppings collected in a radius of approximately $20 \mathrm{~m}$ at random locations within each habitat. In both years, samples were collected at six different locations (with a minimal distance of at least $150 \mathrm{~m}$ ) in the wet tundra habitat. In the mesic tundra habitat, samples were collected at 15 random locations in 1997 and six locations in 2004. In 1990, droppings of individually colour-ringed geese were collected, only in the wet tundra (F. Greve, unpublished data). To make data comparable to those of other years, the average diet composition of 16 individual geese $(8$ males and 8 females) collected on 7-8 July ( 8 samples) and 24-25 July was calculated (8 samples).

All samples were oven dried at $60^{\circ} \mathrm{C}$ for $48 \mathrm{~h}$ and analysed microscopically to determine diet composition on the basis of plant epidermal fragments. Epidermal fragments were identified on the basis of a reference collection of plant epidermal fragments collected in the study area. Water was added to homogenised samples and ten microscopic slides were created for each sample. Per slide, ten plant epidermal fragments along a diagonal line in the slide with fixed intervals were identified. We used the line-intercept method (Seber and Pemberton 1979; Gebzynska and Myrcha 1966) with the modification that only those fragments in the centre of the microscopic field were identified (following Owen 1975) rather than an area of those fragments that intersected the line. By moving the microscopic slide by successive 2-mm steps, the distance between two sample points within the slide was larger than that of the size of plant fragments; this resulted in 100 randomly identified plant fragments per sample.

Experimental grazing trials using captive barnacle geese

\section{Study site 2}

Experimental grazing was carried out in Adventdalen, Spitsbergen $\left(78.2^{\circ} \mathrm{N}, 16.7^{\circ} \mathrm{E}\right)$ in two habitats, which are important goose grazing habitats and can be found throughout Svalbard. One consisted of a wet moss-dominated tundra, the other of mesic tundra as in Ny-Ålesund. In the wet moss-dominated tundra Dupontia fisherii, Equisetum arvense and Saxifraga cernua were the most abundant vascular plant species, whereas Calliergon richardsonii was the most common moss species. The mesic, moss-rich tundra was dominated by Salix polaris, other vascular species present were Alopecurus borealis, Bistorta vivipara and Dryas octopetala. Sanionia uncinata and Tomenthypnum nitens were the most abundant moss species in the mesic tundra. The area is visited by wild barnacle (Branta leucopsis) and pink-footed geese (Anser brachyrhynchus) only during spring and autumn migration. The number of breeding pairs in the area is very low. The lack of a breeding colony of geese in this area can be explained by the absence of suitable breeding and hatching habitat, such as islands and open water for barnacle geese (cf. Loonen et al. 1998) and steep cliffs for breeding pink-footed geese (cf. Wisz et al. 2008). Other naturally occurring herbivores include Svalbard reindeer (Rangifer tarandus platyrhynchus), which graze in low intensity in the study area throughout summer (Wegener and Odasz-Albrigtsen 1998). As a consequence of the low grazing pressure, a relatively high standing plant biomass is found in this area when compared with continuously goose-grazed vegetation near breeding colonies of geese such as in Ny- $̊$ lesund (Loonen and Solheim 1998). The reason why experimental grazing was carried out in this area is that an increase in grazing pressure should resemble the situation when a new goose colony establishes in a relatively unexploited site.

\section{Design experimental grazing trials}

Four (in 2003 and 2005) and six (2004) wild adult barnacle geese (Branta leucopsis), caught in the beginning of the 
breeding season in Svalbard, were used for experimental grazing. Each pair of geese was kept in a $2 \mathrm{~m} \times 2 \mathrm{~m}$ cage and provided with fresh vegetation twice a day outside the experimental periods. We used dark cloth attached on top of the cage to make birds calmer and prevent them from flying up. After a 2-week training period, geese were adapted to the procedures used in the grazing experiment and calmly started foraging, even when researchers were in close vicinity. To prevent any disturbance, researchers were sitting in observation hides during experimental grazing.

Two grazing experiments were initiated in 2003, as part of a larger experiment studying the effects of grazing and increased surface temperature. The design of the first grazing experiment was a randomised block design in which the effects of grazing (two levels) and increased surface temperature were studied. Temperature was increased by means of open top chambers, which increased soil surface temperature by $1-2^{\circ} \mathrm{C}$ (for further details see Sjögersten et al. 2008). Two levels of grazing were applied on plots of $2 \mathrm{~m} \times 2 \mathrm{~m}$; in 'low level' grazing, a pair of geese was present for $1 \mathrm{~h}$ on a plot and in 'high level' grazing, it was present for $5 \mathrm{~h}$. Each block containing all treatments was replicated five times in the two habitat types; wet-moss tundra and mesic tundra. In the second experiment, a gradient of grazing pressures was created at eight plots $(2 \mathrm{~m} \times 2 \mathrm{~m})$ in each of the two habitats, by placing a pair of geese for a fixed time on each plot $(0,0.5$, $1,2,3,4,5$ and $7 \mathrm{~h}$ ). All grazing treatments were applied two times during the growing season (end of June and end of July) and repeated at the same plots in 2003 and 2004. This allowed for regrowth of plants in between two grazing events. In 2005, only one grazing at the plots took place at the end of June.

Before each grazing trial, geese were starved for $2 \mathrm{~h}$ to ensure that most previously ingested food was out of the digestive tract at the start of grazing (Prop and Vulink 1992), and geese immediately began to feed on the experimental plots. After each grazing trial, geese were put on a wooden board and again starved for $2 \mathrm{~h}$ to empty their intestines. We collected droppings from the wooden board, with this procedure we made sure that the droppings represent the situation at the end of each grazing trial (maximum depletion under a given grazing pressure). In order to estimate food consumption, the total number of droppings produced (the number found on the plot plus the number on the wooden board) was counted. Additionally, on all plots grazed in 2003, five random droppings were collected, oven dried at $60^{\circ} \mathrm{C}$ for $48 \mathrm{~h}$ to determine dropping dry weight. Actual grazing time per plot was estimated by recording the time spent on grazing during $30 \mathrm{~s}$ and every second minute for each goose during experimental grazing in 2003. In 2004 and 2005, each goose was observed for
10 min each hour and the time spent on grazing was recorded.

\section{Experimental grazing versus natural grazing}

Experimental grazing of both experiments resulted in seasonal grazing pressures in mesic tundra ranging between 9 and $140 \mathrm{~min} \mathrm{~m}^{-2}$ in a period of 39-40 days (two bouts of grazing with an interval of 28 days), resulting in 0.23-3.54 min $\mathrm{m}^{-2} \mathrm{day}^{-1}$. How do these levels relate to natural levels of grazing pressure? Few studies report on grazing pressure on mesic tundra areas in Svalbard. In late June, Prop et al. (1984) found a grazing pressure of $0.2-0.3 \mathrm{~min} \mathrm{~m}^{-2} \mathrm{day}^{-1}$ on the most visited part of dry tundra in their study area. This grazing pressure refers to only part of the season, covering the period of 22 June to 8 July. Hence, the lowest values of grazing pressure recorded in the present experiment in the mesic tundra overlap with those found in similar habitat grazed by wild barnacle geese. Maximum levels of experimental grazing pressure exceeded natural levels by a factor 12 in the mesic habitat. In the wet tundra, experimental seasonal grazing pressure ranged from 11 to $218 \mathrm{~min} \mathrm{~m}^{-2}$ in a period of 39-40 days (two bouts of grazing with an interval of 28 days), resulting in $0.28-5.52 \mathrm{~min} \mathrm{~m}^{-2} \mathrm{day}^{-1}$. Natural recorded values ranged from 0.5 to $1.3 \mathrm{~min} \mathrm{~m}^{-2} \mathrm{day}^{-1}$ on wet moss vegetation in July-August (Loonen et al. 1998), whereas Drent et al. (1998) found a value of $0.6 \mathrm{~min} \mathrm{~m}^{-2}$ day $^{-1}$ along lake shores in August. Thus, lowest values of experimental grazing pressure are comparable to natural levels of grazing pressures observed in this habitat, whereas the maximum levels exceeded the natural levels by a factor of 4 .

\section{Chemical analyses of faeces}

A mixed sample of five droppings was collected on the wooden board after grazing and remaining droppings plus five freshly collected ones were added to the grazed plots to prevent the removal of nutrients. A similar sample of plots was collected, which were grazed for $0.5-3 \mathrm{~h}$, as not enough droppings could be found on the plots after grazing. Samples were oven dried at $60^{\circ} \mathrm{C}$ for $48 \mathrm{~h}$ and later chemically analysed. Total nitrogen, as a measure of protein content (Van Soest 1982), was determined by means of automated elemental analysis (Interscience EA 1110). Acid detergent fibre (ADF), a poorly degradable cell wall component of plants (Van Soest 1982; Sedinger et al. 1995a) was determined according to Goering and Van Soest (1970). Next to these chemical analyses, each sample was analysed microscopically to determine diet composition with the method described earlier ("Changes in diet composition in a growing breeding colony"). 


\section{Chemical analyses of plant samples}

Samples of main forage plant species (Equisetum arvense, Dupontia fisherii, Alopecurus borealis, leaves and rhizomes from Bistorta vivipara and the moss Calliergon spp. and Tomenthypnum) were collected at the end of June, first week of July, mid-July and the beginning of August in 2003 , in the area surrounding the experimental plots. During sampling, selective grazing by geese was mimicked by selecting only live leaf tips of every encountered plant or fresh tops of mosses. The samples were oven dried at $60^{\circ} \mathrm{C}$ for $48 \mathrm{~h}$ and, after grinding, the $\mathrm{N}$ content and ADF content were determined as described above. In the calculations of diet quality, we used the N and ADF content of the plant samples that were collected closest to the date of experimental grazing. Nutritional values of plant species which were found in the diet but were not sampled were estimated based on the literature data (Prop and Vulink 1992; Prop and de Vries 1993).

\section{Calculations to determine diet quality and energy IR}

Crude protein content of each food plant $(i-j)$ was calculated by multiplying nitrogen content by 6.25 (Prop and Vulink 1992). Total protein content of the diet $\left(P_{\text {tot }}\right)$ was calculated as the sum of protein content $\left(P_{\mathrm{c}}\right)$ of each food plant multiplied by the fraction of these plants in the diet $\left(F_{\mathrm{c}}\right)$ :

$P_{\text {tot }}={ }_{i} \Sigma^{j}\left(P_{\mathrm{c}} \times F_{\mathrm{c}}\right)$

The total content of ADF in the diet was calculated as described above, followed by the calculation of apparent digestibility $(D)$ of the food (proportion on an ash free basis) according to Van Soest (1982):

$D=1-\left(M_{\mathrm{f}} / M_{\mathrm{d}}\right)$

where $M_{\mathrm{f}}$ and $M_{\mathrm{d}}$ are the concentrations of a poorly digestible marker (ADF) in the food and droppings, respectively. As a small proportion of ADF may be digested in spring (Prop and Vulink 1992), estimates of digestibility are conservative. Mf was calculated as described above. Md was directly determined from dropping samples taken after each grazing event.

Dropping numbers counted after grazing were converted to total dropping weight by multiplying dropping number by the average dropping dry weight. As dropping weight did not change with hours of grazing (wet habitat: $F_{1,13}=0.39, P=0.55$, mesic habitat: $F_{1,12}=0.86$, $P=0.38$ ) and there was no significant difference between the wet and mesic habitat $\left(t_{1}, 25=-0.96\right.$, $P=0.35)$ overall dropping dry weight of $0.49 \mathrm{~g}$ was used. Dry mass IR was calculated according to Prop and Black (1998):
$\mathrm{IR}=$ Dropping weight $/(1-D)$

For each plant species $(i-j)$, the metabolisable energy IR (MEIR) was obtained by multiplying the gross intake rate $\left(\mathrm{IR}_{i}\right)$ by the (apparent) metabolisable energy content $\left(\mathrm{ME}_{i}, \mathrm{~kJ} \mathrm{~g}^{-1}\right.$ dry matter; Karasov 1990). Values of the ME of each food plant in July and August were taken from (Prop and Vulink 1992). Total metabolisable energy intake rate MEIR $_{\text {tot }}$ was calculated by summing all MEIR's for each species as (see also Prop and de Vries 1993):

$\operatorname{MEIR}_{\mathrm{tot}}={ }_{i} \Sigma^{j} \mathrm{ME}_{i} \times \mathrm{IR}_{i}$

From literature, an estimate of daily energy expenditure of an average barnacle goose $(1,800 \mathrm{~g})$ was obtained. These estimates were based on daily metabolisable energy intake and time energy budgets in wild barnacle geese wintering in the Netherlands (Ebbinge et al. 1975; Owen et al. 1992) and on heart rate and doubly labelled water techniques of exercising barnacle geese (Nolet et al. 1992). Our assumption is that the relatively mild-Dutch winter conditions in maritime climate (average January temperature of ca. $2^{\circ} \mathrm{C}$ ) provide a reasonable estimate of the energy expenditure for geese in summer on Svalbard (average June-July temperature of $2-6^{\circ} \mathrm{C}$ ). In general, the workload for Anseriformes under field conditions is ca. 1.8 times the energy expenditure at rest (Nolet et al. 1992; Eerden 1998). This resulted in a daily energy expenditure of $806 \mathrm{~kJ} \mathrm{day}^{-1}$, for an average adult barnacle goose under field conditions. On the breeding grounds in High Arctic Svalbard, $24 \mathrm{~h}$ of day light is available for foraging due to continuous day light. Based on the assumption that a goose can use these $24 \mathrm{~h}$ of daylight in the High Arctic, the minimum MEIR should be $33.6 \mathrm{~kJ} \mathrm{~h}^{-1}$, to meet its daily energy requirements.

\section{Statistical analyses}

Differences in diet composition of wild geese between years were tested by means of multivariate GLM for the wet and mesic tundra separate, followed by Tukey multiple comparison for those plant species in the wet tundra that showed significant effects of years. For the experimental grazing experiment with randomised block design, first, overall effects of treatments (two levels of goose grazing and increased surface temperature) were tested on diet composition and diet quality (protein, ADF and MEIR) using univariate GLMM for the wet and mesic habitat separately. Treatment effects were treated as fixed factors and block as a random factor. Grazing treatment was the main factor affecting significantly the tested parameters (Table 1). As there were no significant block effects or interactions between factors, the temperature significantly affected only protein content of diet 
Table 1 Results of GLM analyses of overall treatment effects (enhanced surface temperature and two levels of goose grazing pressure) and block (in which each treatment was present) on diet composition, diet quality (total protein content, ADF content and metabolisable energy content of diet) and intake rate of geese

\begin{tabular}{|c|c|c|c|c|c|c|c|c|c|c|c|c|c|}
\hline \multirow[t]{2}{*}{ Habitat } & \multirow[t]{2}{*}{ Parameter } & \multicolumn{2}{|c|}{ Temperature } & \multicolumn{2}{|c|}{ Grazing } & \multicolumn{2}{|l|}{ Block } & \multicolumn{2}{|c|}{ Temp. $\times$ grazing } & \multicolumn{2}{|c|}{ Temp. $\times$ block } & \multicolumn{2}{|c|}{ Grazing $\times$ block } \\
\hline & & $F_{1,15}$ & $P$ & $F_{1,15}$ & $P$ & $F_{4,15}$ & $P$ & $F_{1,15}$ & $P$ & $F_{4,15}$ & $P$ & $F_{4,15}$ & $P$ \\
\hline \multirow[t]{10}{*}{ Wet } & Equisetum & 0.08 & 0.79 & 29.25 & 0.01 & 0.55 & 0.71 & 0.57 & 0.49 & 3.50 & 0.13 & 1.62 & 0.33 \\
\hline & Moss & 0.70 & 0.45 & 3.70 & 0.13 & 0.23 & 0.90 & 0.07 & 0.81 & 0.96 & 0.52 & 1.56 & 0.34 \\
\hline & Dupontia & 0.61 & 0.48 & 6.64 & 0.06 & 1.90 & 0.43 & 0.09 & 0.79 & 0.81 & 0.58 & 1.20 & 0.43 \\
\hline & Monocots & 0.17 & 0.68 & 1.741 & 0.26 & - & - & 0.89 & 0.40 & 0.33 & 0.85 & 0.36 & 0.83 \\
\hline & Dicots & 0.50 & 0.52 & 1.81 & 0.25 & 1.89 & 0.29 & 2.66 & 0.18 & 5.13 & 0.07 & 1.15 & 0.45 \\
\hline & Protein diet & 0.19 & 0.68 & 11.72 & $\mathbf{0 . 0 3}$ & 0.25 & 0.90 & 0.14 & 0.73 & 1.76 & 0.30 & 1.54 & 0.34 \\
\hline & $\mathrm{ADF}$ diet & 0.30 & 0.61 & 8.0 & 0.05 & 0.23 & 0.91 & 0.11 & 0.76 & 1.39 & 0.38 & 1.59 & 0.33 \\
\hline & ME diet & 0.48 & 0.52 & 2.84 & 0.17 & 0.14 & 0.95 & 0.00 & 0.98 & 1.03 & 0.48 & 1.75 & 0.30 \\
\hline & Digestibility & 0.01 & 0.91 & 0.03 & 0.86 & 0.28 & 0.88 & 2.46 & 0.22 & 2.85 & 0.21 & 2.21 & 0.27 \\
\hline & Intake rate & 0.81 & 0.42 & 32.34 & 0.03 & 4.32 & 0.82 & 0.08 & 0.81 & 0.77 & 0.63 & 0.50 & 0.67 \\
\hline \multirow[t]{10}{*}{ Mesic } & Moss & 2.51 & 0.19 & 0.17 & 0.70 & 0.17 & 0.94 & 2.51 & 0.19 & 1.06 & 0.48 & 1.40 & 0.38 \\
\hline & Alopecurus & 5.95 & 0.07 & 4.24 & 0.11 & 0.81 & 0.59 & 0.05 & 0.83 & 0.89 & 0.54 & 2.71 & 0.18 \\
\hline & Bistorta & 3.07 & 0.16 & 10.40 & 0.03 & 1.48 & 0.52 & 0.49 & 0.52 & 0.81 & 0.58 & 1.12 & 0.46 \\
\hline & Monocots & 0.36 & 0.58 & 1.63 & 0.27 & 0.19 & 0.93 & 10.24 & $\mathbf{0 . 0 3}$ & 3.27 & 0.14 & 23.60 & 0.01 \\
\hline & Dicots & 1.79 & 0.23 & 1.16 & 0.34 & 0.15 & 0.95 & 2.99 & 0.16 & 1.73 & 0.30 & 1.52 & 0.35 \\
\hline & Protein diet & 16.47 & 0.02 & 6.14 & 0.07 & 1.14 & 0.53 & 0.17 & 0.70 & 0.37 & 0.82 & 2.39 & 0.21 \\
\hline & ADF diet & 1.34 & 0.31 & 11.94 & 0.03 & 1.87 & 6.43 & 1.08 & 0.36 & 0.77 & 0.60 & 0.71 & 0.63 \\
\hline & ME diet & 4.22 & 0.11 & 0.91 & 0.40 & 0.29 & 0.87 & 1.87 & 0.24 & 1.41 & 0.37 & 3.88 & 0.11 \\
\hline & Digestibility & 0.81 & 0.42 & 10.98 & 0.03 & 0.47 & 0.78 & 0.82 & 0.42 & 1.10 & 0.47 & 0.85 & 0.56 \\
\hline & Intake rate & 2.3 & 0.65 & 4.81 & 0.09 & 0.46 & 0.77 & 0.01 & 0.93 & 1.17 & 0.44 & 1.16 & 0.45 \\
\hline
\end{tabular}

Data of diet composition were arcsine transformed prior to analyses. Significant effects on parameters are indicated in bold

in the mesic tundra (Table 1), the effects of grazing pressure were further explored. As there was a large variation in the actual grazing time on each plot, data were analysed in relation to actual grazing pressure on a plot rather than making use of the randomised block design with two grazing intensities. In these analyses, we combined all experimentally grazed plots $(n=25$ in each habitat) from both grazing experiments (randomised block design and gradient of grazing pressure). Patterns in diet composition, diet quality and MEIR in relation to cumulative grazing pressure $\left(\operatorname{min~} \mathrm{m}^{-2}\right)$ in the end of 2004 were used, as the range in grazing pressures was largest in this year. Patterns in 2003 and 2005 were not statistically different from 2004 but less pronounced. As on some plots in the wet habitat no correct dropping counts could be performed due to trampling by the geese, sample sizes of IR and MEIR are smaller than the number of plots that was grazed. We used linear regressions to test for a relationship between grazing pressure and parameters of diet quality and MEIR. To describe the use of food plants, we also fitted quadratic and logarithmic functions as these patterns may show an optimum or decrease/increase logarithmically with grazing pressure. As linear and logarithmic regressions have the same number of parameters to be estimated, choice between models could not be based on any significant improvement of fit. When both fits were significant, we chose the logarithmic fit if this had a higher $R^{2}$ value (by at least 0.05) than the linear fit. Quadratic fit was tested by means of $F$ test whether it resulted in a significant better fit than the other curves (Huisman et al. 1993). In order to analyse how foraging condition change between years, we used the data of the first grazing event only, as this was done in all years of the study (second grazing absent in 2005). To test whether MEIR significantly differs between consecutive years at the same level of grazing pressure, the procedure for a two-tailed test for comparing points on two regression lines described in Zar (1984) was used. This method entails the calculation of a $t$ value based on the predicted $y$ values at a given $x$ value of two regression lines (for further details see Zar 1984). All percentage data were arcsine transformed prior to analyses (Zar 1984), untransformed data are shown in graphs. All analyses were performed using SPSS statistical package, version 15.0. 


\section{Results}

Changes in diet composition in a wild goose population

Diet composition of wild geese on continuously grazed vegetation in the breeding colony of Ny-Ålesund showed clear changes between years (Fig. 1a, b). In the wet tundra, the proportion of the graminoid Poa arctica, decreased from 39\% in 1990 to less than $8 \%$ in $2004\left(F_{2,28}=6.13\right.$, $P=0.007)$. Between 1990 and 1997, there was an increase in proportion of other graminoids $\left(F_{2}, \quad 28=14.14\right.$, $P<0.0001$ ), mainly consisting of Deschampsia alpina, which was virtually absent in 2004 . Also, the proportion of dicots decreased in the period 1990-1997 $\left(F_{2,28}=12.35\right.$, $P<0.0001)$. The only food item that increased was moss, constituting $29 \%$ in 1990 and $91 \%$ in $2004\left(F_{2,28}=21.7\right.$, $P<0.0001)$. In the mesic tundra, a decrease of $\mathrm{Poa}$ $\operatorname{arctica}\left(F_{1,21}=26.57, P<0.0001\right)$ and other monocots
$\left(F_{1,21}=36.84, P<0.0001\right)$ coincided with an increasing proportion of dicots $\left(F_{1,21}=43.28, P<0.0001\right)$. The proportion of moss also tended to increase $\left(F_{1,21}=3.53\right.$, $P=0.076)$. The increasing proportion of dicots consisted mainly of above and below ground materials of Bistorta vivipara.

Seasonal exploitation of food plants in relation to experimental grazing pressure

At low levels of experimental grazing, in the wet tundra (Fig. 2a-c), geese mainly foraged on horsetail, Equisetum arvense. Diet consisted up to $90 \%$ of this species. The proportion of Equisetum in the diet decreased logarithmically with increasing grazing pressure $(y=129.6+$ $\left.(-23.38 \ln (x)), R^{2}=0.61, F_{1,23}=35.70, P<0.001\right)$. At intermediate levels of grazing, geese switched to the grass Dupontia fisherii $\left(y=-0.002 x^{2}+0.62 x-6.89 ; R^{2}=\right.$
Fig. 1 Diet composition of wild geese during different stages of breeding population development in Ny-Alesund, Kongsfjorden in continuously grazed wet tundra (a) and mesic tundra (b) habitats. Since the 1980s, a goose colony has been established in this area. Proportions in 1997 and 2004 are averages based on 5-6 droppings collected at six random locations $(n=6)$ in the wet tundra or 6-15 random locations in the mesic tundra. Diet composition in 1990 is based on the average of droppings from 16 individually colour-ringed geese (see "Methods" for further details). Different letters indicate significant differences between plant categories in diet between years (a)

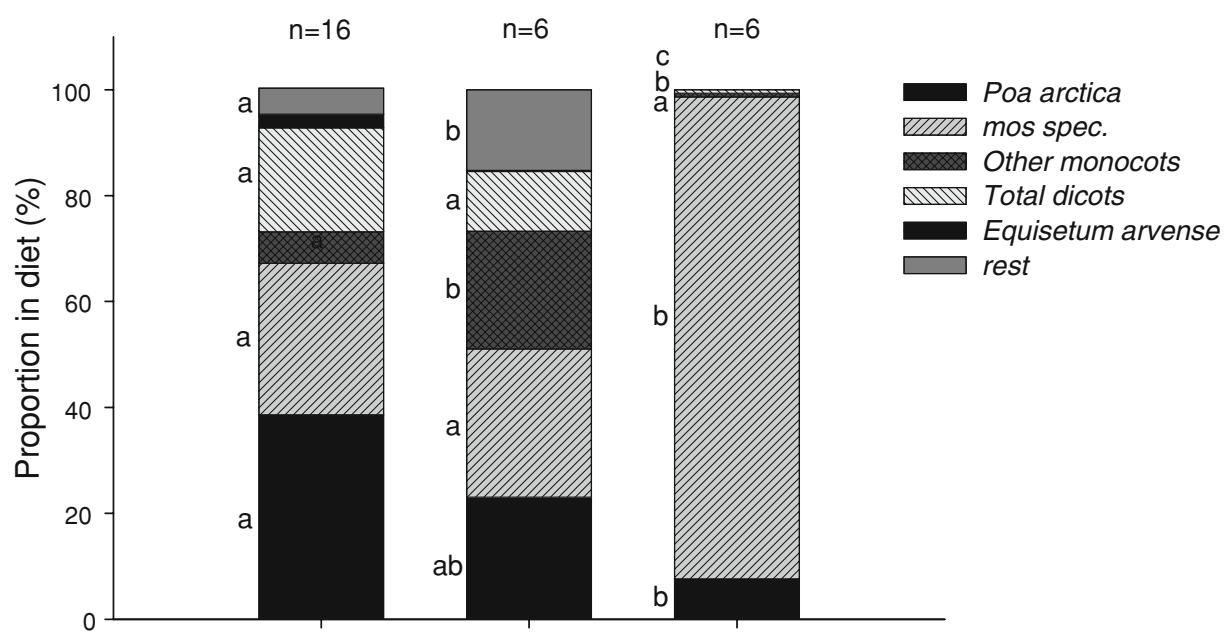

(b)

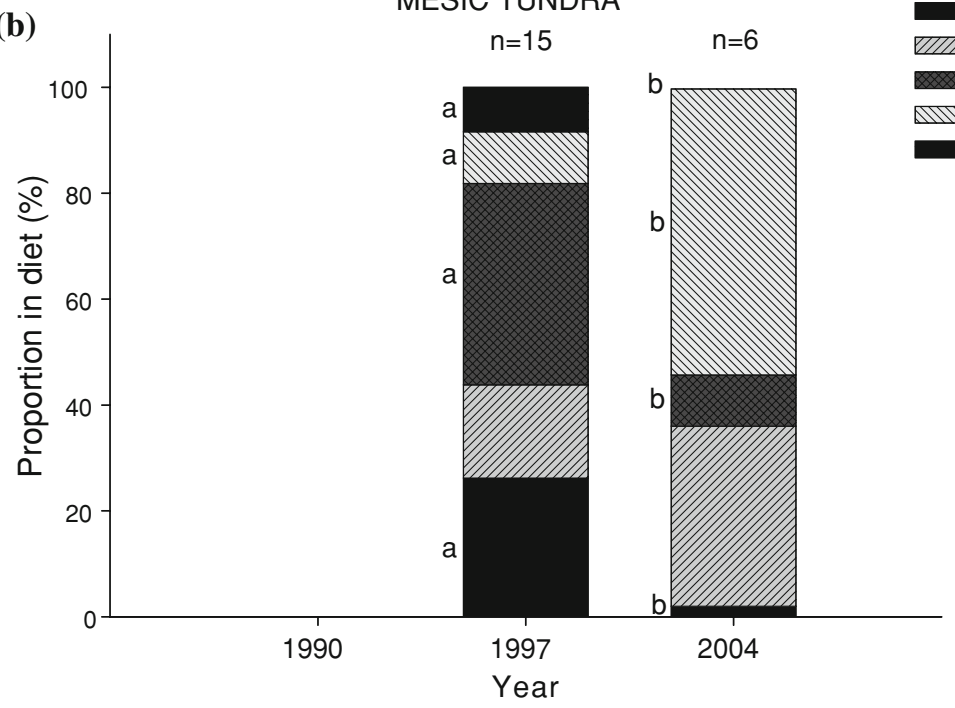

WET TUNDRA

Poa arctica IIIIs Mos spec. Other monocots IIIIV Total dicots Rest 
Fig. 2 Proportion of dominant food items in the wet tundra (ac Equisetum arvense, Dupontia fisherii and moss spp.), and mesic tundra (d-f Alopecurus borealis, Bistorta vivipara and moss spp.) in the diet of geese in relation to yearly experimental grazing pressure in 2004. Grazing occurred two times during the growing season (end of June and end of July). Only food plants which constitute more than $10 \%$ of the diet are shown. Lines indicate the best significant fit through the data, see text for statistics
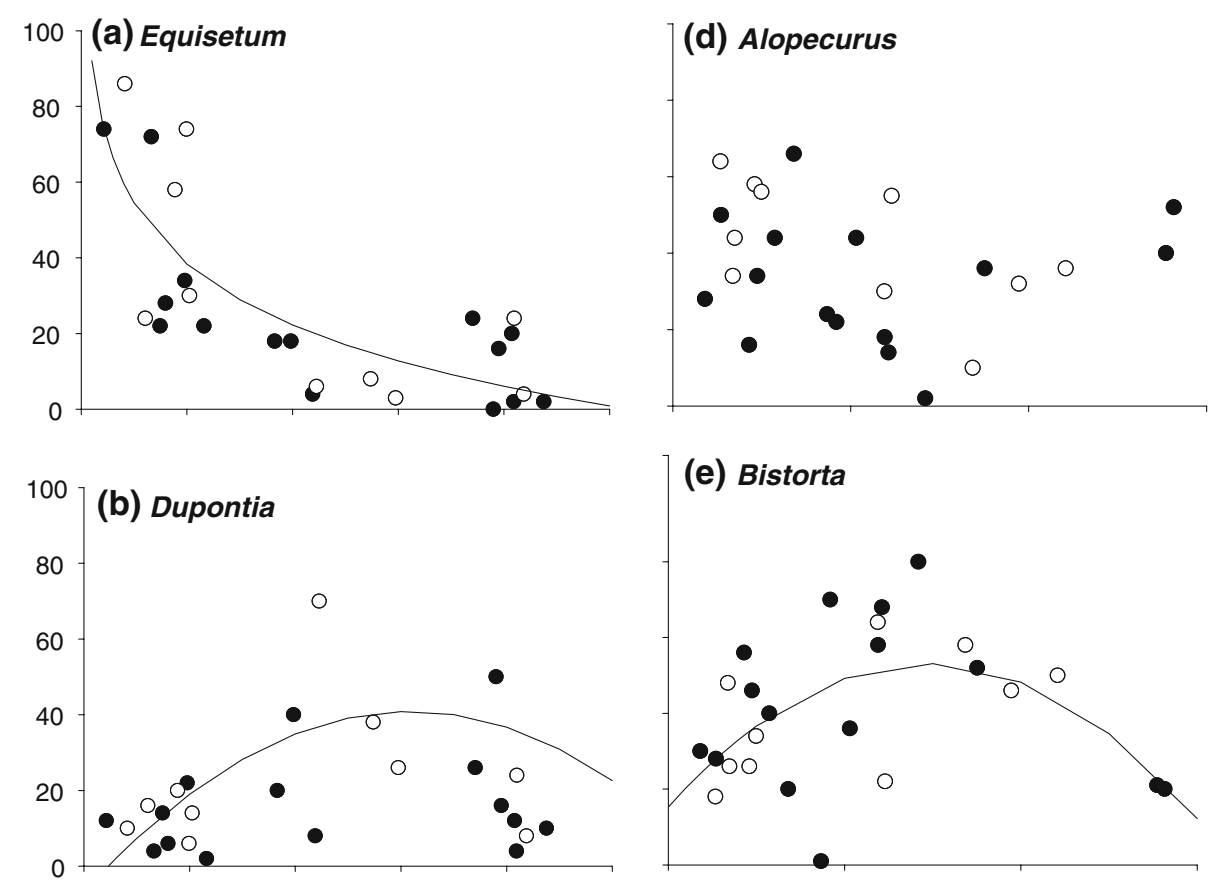

(e) Bistorta
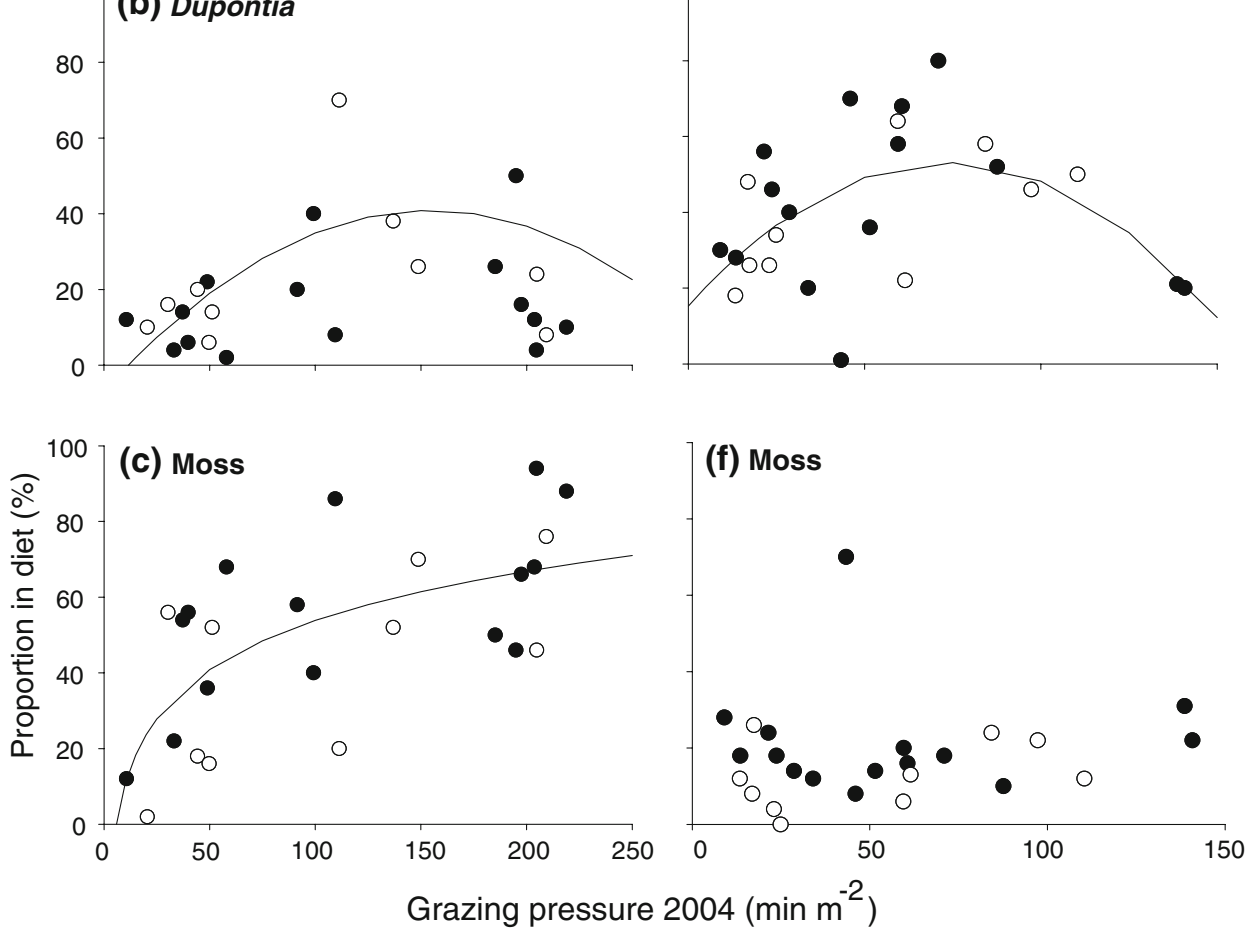

Grazing pressure $2004\left(\mathrm{~min} \mathrm{~m}^{-2}\right.$ )

- Ambient temperature $\circ$ Temperature increased $\left.0.30, F_{2,22}=4.60, P=0.021\right)$. The amount of mosses in the diet increased with grazing pressure and dominated the diet at highest levels of grazing $(y=-32.51+(18.75$ $\left.\ln (x)), R^{2}=0.42, F_{1,23}=16.71, P=0.001\right)$. The proportion of dicots in the diet (mainly Bistorta vivipara, Salix polaris and Ranunculus hyperboreus) and other monocots (Eriophorum scheuchzeri and Calamagrostis stricta) did not change in relation to grazing pressure $(P>0.1$ and $P>0.3$, respectively).

Patterns of food plant exploitation were less pronounced in the mesic tundra (Fig. 2d-f). The grass Alopecurus borealis comprised a high proportion of the diet, which was not related to grazing pressure $(P>0.07$, on average $36.3 \pm 3.4 \%$ of the diet). Bistorta vivipara was most used at intermediate levels of grazing pressure $\left(y=-0.007 x^{2}+\right.$ $\left.1.03 x+15.26, R^{2}=0.295, \quad F_{2}, \quad 22=4.60, \quad P=0.021\right)$, whereas, the amount of mosses did not change in relation to grazing pressure $(P>0.6$, on average $18 \pm 2.7 \%)$. Other dicots (mainly Salix polaris, Ranunculus spp. and Stellaria longipes) and other monocots (mainly Poa arctica and Luzula confusa) constituted only a small proportion of the diet, on average $3.2 \%( \pm 0.6)$ and $1.7 \%( \pm 0.4)$, respectively, and were therefore ignored in the analyses.

Diet quality, IR and energy intake in relation to seasonal grazing pressure

The observed shifts in species composition of diet in relation to grazing pressure (after the second grazing in 2004) affected diet quality. In wet tundra, geese selected species with high protein content, low in fibre (ADF) and high in metabolisable energy at low levels of grazing 
Table 2 Chemical composition of important food plants

\begin{tabular}{|c|c|c|c|c|}
\hline Habitat & Plant species & Protein $(\%)$ & $\operatorname{ADF}(\%)$ & $\operatorname{ME}\left(\mathrm{kJ} \mathrm{g}^{-1}\right)^{\mathrm{a}}$ \\
\hline \multirow[t]{5}{*}{ Wet } & Equisetum arvense & $25.3 \pm 2.3$ & $17.8 \pm 1.3$ & 8.8 (Equisetum variegatum) \\
\hline & Dupontia fisherii & $18.7 \pm 2.3$ & $26.2(1.3)$ & 9.2 \\
\hline & Moss (Calliergon sp.) & $11.9 \pm 0.4$ & $47.7 \pm 2.7$ & 3.1 \\
\hline & Other monocots & - & - & 9.2 \\
\hline & Dicots & - & - & 7.8 \\
\hline \multirow[t]{6}{*}{ Mesic } & Alopecurus borealis & $16.9 \pm 2.3$ & $24.6 \pm 0.6$ & 9.2 \\
\hline & Bistorta vivipara (rhizome) & $7.2 \pm 0.7$ & $31.4 \pm 3.6$ & 7.8 \\
\hline & Moss (Tomentyphnum sp.) & $5.0 \pm 0.5$ & $40.8 \pm 1.2$ & 3.1 \\
\hline & Other monocots & - & - & 9.2 \\
\hline & Other dicots & & & \\
\hline & Bistorta vivipara leaf & $20.2 \pm 1.5$ & $28.8 \pm 0.7$ & 7.8 \\
\hline
\end{tabular}

Protein content and ADF are expressed as proportion of ash-free dry weight. Numbers represent mean values of samples collected at the end of June, first week of July, mid-July and the beginning of August in $2003(n=4)$ and standard errors

${ }^{a}$ From Prop and de Vries (1993)

(Table 2). This was contrasted in a decreasing protein content $\left(R^{2}=0.48, \quad F_{1}, \quad 24=21.53, \quad P<0.0001\right)$ and increasing ADF content $\left(R^{2}=0.46, \quad F_{1}, 24=19.53\right.$, $P<0.0001)$ of the diet with increased grazing pressure. Consequently, metabolisable energy content of the diet decreased with grazing pressure $\left(R^{2}=0.35, F_{1,21}=12.56\right.$, $P=0.002)$. In the mesic tundra protein, ADF and metabolisable energy content of the diet did not change with grazing pressure (protein: $F_{1,24}=0.060, P=0.81$, ADF: $F_{1,24}=0.013, P=0.91$, metabolisable energy: $F_{1,24}=$ $0.59, P=0.45$ ).

In contrast to the diet quality, dry matter IR decreased in both the wet $\left(R^{2}=0.45, F_{1,16}=12.08, P=0.003\right)$ and the mesic tundra $\left(R^{2}=0.26, F_{1}, 23=7.83, P=0.01\right)$. As available plant biomass of selected plant species was lower in the mesic tundra than that in the wet tundra (E.J. Cooper, unpublished data), IR was lower at all levels of grazing pressure at the mesic tundra. Dry matter IRs were combined with metabolisable energy content of the diet to calculate the MEIR. The MEIR was negatively related with grazing pressure in both the wet $\left(R^{2}=0.43, F_{1,16}=11.50\right.$, $P=0.004)$ and mesic $\left(R^{2}=0.24, \quad F_{1}, \quad 24=7.35\right.$, $P=0.012)$ tundra sites indicating the overriding importance of IR above diet quality (Fig. 3). Assuming that geese can forage during the $24 \mathrm{~h}$ of daylight in the high Arctic, at a seasonal grazing pressure beyond $147 \mathrm{~min} \mathrm{~m}^{-2}$ in the wet tundra and $83 \mathrm{~min} \mathrm{~m}^{-2}$ in the mesic tundra the MEIR dropped below the minimum MEIR needed to meet their estimated daily energy requirements (Fig. 3). At the currently observed ranges in natural grazing pressure in these habitats (Fig. 3), MEIRs were well above (wet tundra) or close to (mesic tundra) the minimum requirements, whereas values were below or close to minimum MEIR when levels exceeded natural grazing pressure.

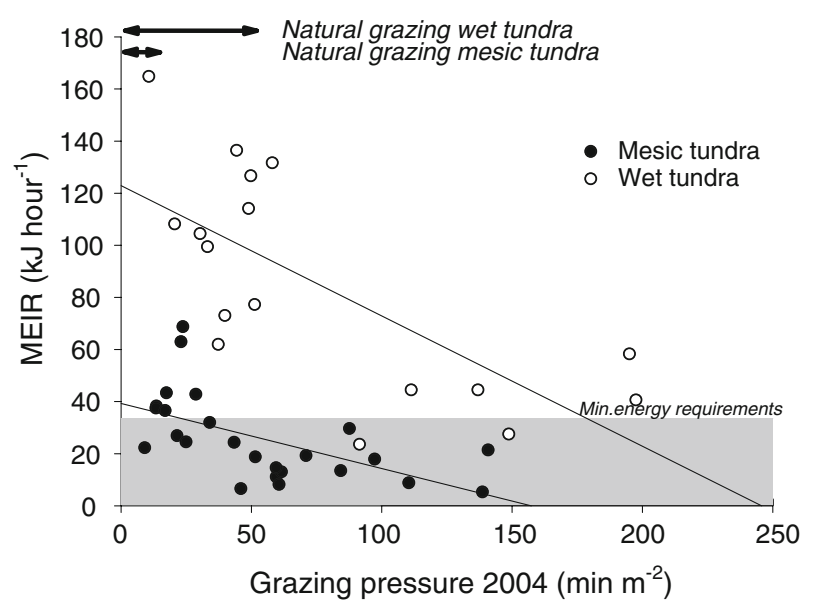

Fig. 3 The metabolisable energy intake rate (MEIR) of geese in relation to yearly experimental grazing pressure in 2004 for the wet and mesic tundra. Grazing occurred two times during the growing season (end of June and end of July). Geese are time constrained when their MEIR is lower than $33.6 \mathrm{~kJ} \mathrm{~h}^{-1}$ as they cannot meet their daily requirements of $806 \mathrm{~kJ}$ (Nolet et al. 1992; Eerden 1998) even when feeding during $24 \mathrm{~h}$ of daylight. Arrows indicate natural recorded range of grazing pressure in mesic and wet tundra in similar time span as experimental grazing

Foraging conditions in successive years

In order to study how increased grazing pressure influences subsequent foraging conditions, MEIR was plotted against the yearly grazing pressure during the first grazing event in each successive year (Fig. 4). In the wet tundra in 2003, beyond a grazing pressure of $90 \mathrm{~min} \mathrm{~m}^{-2}$ in the beginning of the season, MEIR was too low to meet daily energy requirements (Fig. 4a; $R^{2}=0.40, \quad F_{1}, \quad 24=15, \quad 10$, $P=0.001)$. In the two succeeding years, already at a lower grazing pressure, beyond $56 \mathrm{~min} \mathrm{~m}^{-2}$, energy requirements 
Fig. 4 The metabolisable energy intake rate (MEIR) of geese in relation to yearly grazing pressure in the years 2003-2005 (only for the first grazing event) for the wet (a) and mesic tundra (b). Geese are time constrained when their MEIR is lower than $33.6 \mathrm{~kJ} \mathrm{~h}^{-1}$ as they cannot meet their daily requirements of $806 \mathrm{~kJ}$ (Nolet et al. 1992; Eerden 1998) even when feeding during $24 \mathrm{~h}$ of daylight. Arrows indicate natural recorded range of grazing pressure in mesic and wet tundra in similar time span as experimental grazing
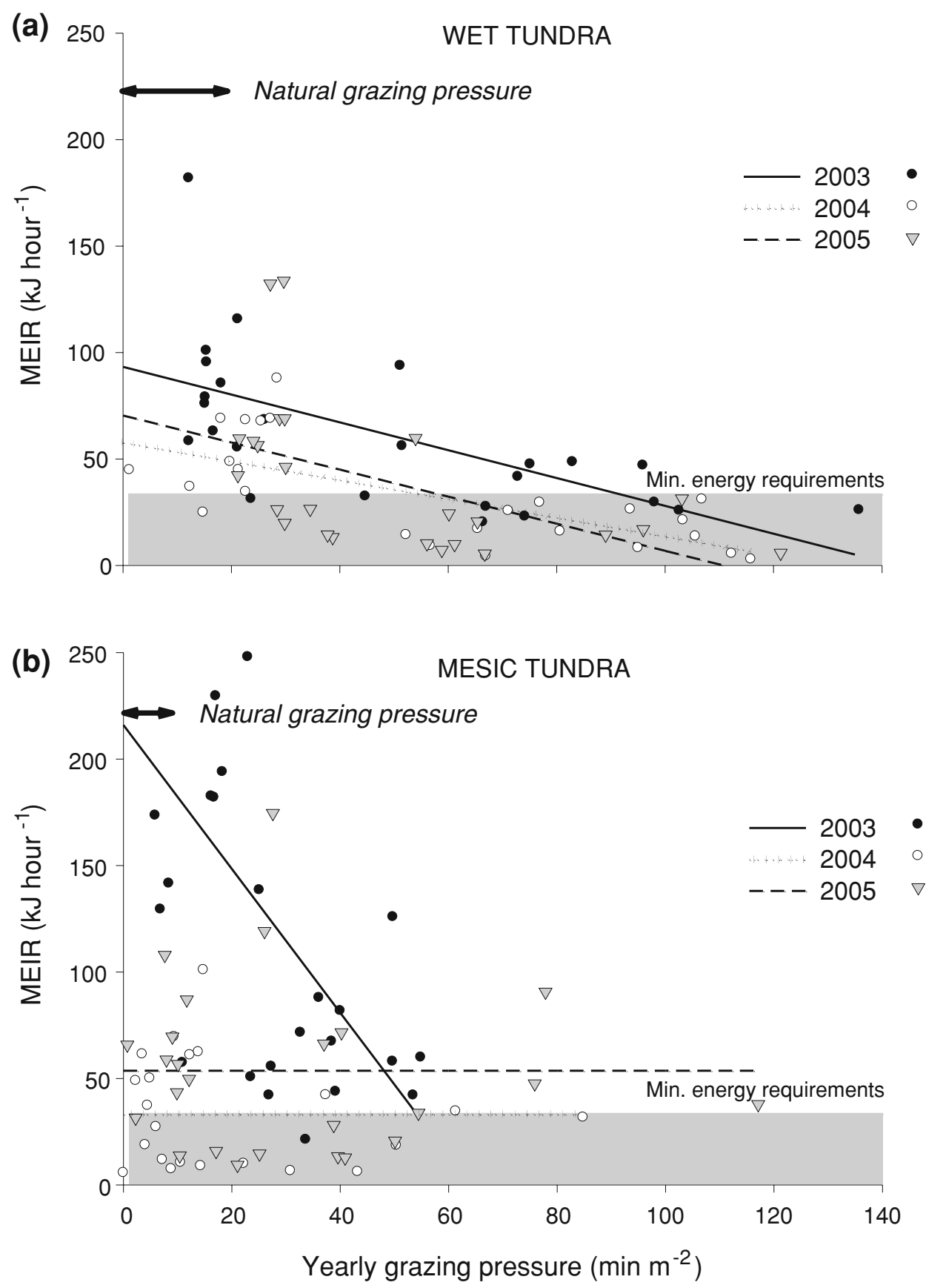

could not be met (2004: $R^{2}=0.47, F_{1}, \quad 24=20.6$, $\left.P<0.0001 ; 2005: R^{2}=0.26, F_{1,24}=8.0, P=0.009\right)$. At this grazing pressure of $56 \mathrm{~min} \mathrm{~m}^{-2}$, MEIR in 2003 was significantly higher when compared to that in $2004\left(t_{2,44}=\right.$ $2.180, P<0.05)$ and marginally significantly higher to that in $2005\left(t_{2,44}=1.941,0.05<P<0.10\right)$ (Table 3$)$.

Although MEIR at low grazing pressure in 2003 in the mesic tundra was higher than in the wet tundra, it decreased more sharply than that in the wet tundra (Fig. 4b). In 2003, beyond a grazing pressure of $54 \mathrm{~min}^{-2}$, minimum energy requirements of geese were not met $\left(R^{2}=0.28, F_{1,23}=8.6\right.$, $P=0.008$ ), whereas in 2004 and 2005 geese MEIR was not related to grazing pressure $\left(2004: R^{2}=0.02, F_{1,21}=0.4\right.$, $\left.P=0.5 ; 2005: R^{2}=0.007, F_{1,24}=0.17, P=0.6\right)$. In 2004 and 2005, values of MEIR were not significantly different from the minimal energy requirement for barnacle geese. While being grazed for several years, the grazing pressure at which vegetation can just provide enough resources to meet the daily energy requirements of grazing geese declines in both habitats. 
Table 3 Results from linear regression with grazing pressure in 2003, 2004 and 2005 entered as independent variable and metabolisable energy intake rate (MEIR) as dependent variable

\begin{tabular}{llll}
\hline Habitat & Year & $\begin{array}{l}\beta(95 \% \text { confidence } \\
\text { interval })\end{array}$ & $\begin{array}{l}b(95 \% \text { confidence } \\
\text { interval })\end{array}$ \\
\hline Wet & 2003 & $-0.65(-1.00 /-0.31)$ & $93.28(72.27 / 114.29)$ \\
& 2004 & $-0.44(-0.64 /-0.24)$ & $57.76(44.21 / 71.31)$ \\
& 2005 & $-0.64(-1.10 /-0.17)$ & $70.43(44.12 / 96.73)$ \\
Mesic & 2003 & $-3.38(-5.76 /-0.99)$ & $215.94(141.08 / 290.79)$ \\
& 2004 & $-0.17(-0.71 /-0.38)$ & $36.55(20.37 / 52.72)$ \\
& 2005 & $-0.12(-0.74 / 0.49)$ & $57.39(32.07 / 82.70)$ \\
\hline
\end{tabular}

The regression coefficient $(\beta)$ and constant of regression model $(b ; Y=\beta x+b)$ and their $95 \%$ confidence interval are shown

\section{Discussion}

The present study showed that shifts in diet composition occurred at different stages of population development in a growing breeding colony of barnacle geese on Svalbard. Similar patterns were found in relation to grazing pressure in experimental grazing trials with captive barnacle geese in a previously unexploited area. Dietary shifts were associated with a decreasing diet quality and/or metabolisable energy IR. During successive years of experimental grazing, foraging conditions deteriorated at grazing pressures exceeding natural recorded levels of grazing. This suggests that high-quality forage plants become rapidly depleted with increasing grazing pressure, and foraging conditions are not improving by increased plant production following extra nutrient input via droppings.

\section{Depletion of preferred food plants}

Upon arrival at the breeding grounds on Svalbard, barnacle geese start grazing in snow-free mesic tundra habitats (Prop et al. 1984), whereas later during the season wet moss-dominated tundra habitats become more important (Prop et al. 1984; Stahl and Loonen 1998). Graminoids make up an important part of the diet of barnacle geese in summer, ranging between 26 and 80\% (Prop and Vulink 1992; Stahl and Loonen 1998). During early May, before the onset of plant growth, mosses are the main food item (up to $90 \%$, Prop and Vulink 1992). Compared to graminoids, mosses contain low protein content and a high proportion of structural carbohydrates which results in low digestibility. Dicots show intermediate values between graminoids and mosses (Prop and Vulink 1992).

The shifts in diet composition of wild geese, observed in the present study, occurring in the breeding area in both wet and mesic continuously grazed tundra vegetation suggest changes in the abundance of high-quality food plants. In wet tundra habitat, the proportion of the graminoid Poa arctica, and dicots decreased continuously in the period 1990-2004 and were replaced by increasing proportion of mosses (increasing from 29 to $90 \%$ ). Similar patterns were observed at the mesic tundra, where graminoids decreased and dicots and mosses increased. These changes in diet coincided with increasing goose numbers in the area from 196 adults in 1990 (Loonen et al. 1998) to ca. 900 adults in 1999 followed by fluctuating numbers, between 800 and 450 adults, until 2004 (M.J.J.E. Loonen, unpublished data). Long-term monitoring of permanent plots in this study area, inside and outside exclosures, illustrated that vegetation changed in the presence of geese throughout this period. Horsetail disappeared from grazed areas and the biomass of grasses decreased (Loonen and Solheim 1998; Kuijper et al. 2006). Due to increasing or continuously high grazing pressure, the abundance of preferred food plants decreased or was more rapidly depleted during the growing season (Sedinger and Raveling 1984). This was confirmed by the observed switches in diet in relation to grazing pressure during experimental grazing in unexploited vegetation. At low levels of grazing pressure, graminoids constituted the most important part of the diet in wet and mesic tundra habitat. With increasing grazing pressure, the proportion of moss increased in wet tundra, whereas, the proportion of dicots increased on mesic tundra. These changes were accompanied by decreasing diet quality and metabolisable IR.

Previous studies illustrated that the presence of foxes have large effects on the habitat use of geese and hence exploitation of food plants in the study area (Loonen et al. 1998; Stahl and Loonen 1998). In years when foxes are present, wet tundra areas are more intensively grazed, whereas, mesic tundra areas showed lower visitation. Although, the presence of foxes may have important additional effects on the depletion of food plants, the diet shifts that were observed in both the wet and mesic tundra in combination with long-term vegetation changes strongly suggest that the entire breeding area is changing.

In general, diet composition of captive geese used during experimental grazing was very similar to that observed for wild geese (see also Prop and Vulink 1992; Stahl and Loonen 1998), with one exceptional plant species; horsetail Equisetum arvense. Captive geese showed a high preference for this species and diet was dominated by Equisetum at low levels of grazing pressure (up to 90\%), whereas it was virtually absent in the diet of wild geese. This difference reflects the difference in abundance of this plant species between the different study areas; it is abundant in the area of experimental grazing, whereas it is virtually absent on continuously grazed vegetation inside the breeding colony in Ny-Ålesund (Kuijper et al. 2006). A rapid depletion of Equisetum early in spring (Prop et al. 1984; Prop and de Vries 1993) provides one explanation 
for its absence in continuous goose-grazed vegetation. A second explanation is that long-term changes in plant species composition, as a result of goose grazing, have resulted in a decreasing abundance of Equisetum. This is supported by the higher occurrence of this species inside plots which excluded goose grazing for over 7 years in this area (Kuijper et al. 2006).

Changing foraging conditions: potential for feedback mechanisms

Both positive and negative effects of increased goose grazing pressure on foraging conditions in breeding areas in arctic ecosystems have been observed. Increased grazing by black brants, Branta bernicla nigricans, in the Alaskan arctic led to an increase in the areal extent of grazing lawns consisting of the preferred high-quality food plant (Person et al. 2003). The authors suggested that these herbivoremediated changes resulted in a numerical increase of the population in the subsequent decades. Contrastingly, increased grazing by lesser snow geese, Anser caerulescens, in Canadian subarctic salt marshes led to the disappearance of principal food plants, creating unvegetated marshes (Zellmer et al. 1993; Gadallah and Jefferies 1995b) over a large areal extent (Jefferies et al. 2006) with fitness consequences for goslings (Cooch et al. 1993) and adults (Williams et al. 2005). Two factors are important in understanding the contrasting effects of goose grazing demonstrated by these studies. First, geese from the Branta genus are grazing only on the above-ground parts of plants, whereas geese from the Anser genus additionally grub for below-ground plant parts (Esselink et al. 1997; Jefferies and Rockwell 2002) which may lead to stronger effects on the plant community (Zacheis et al. 2001). Secondly, in contrast to black brants, foraging by lesser snow geese indirectly changed abiotic conditions (Jefferies and Rockwell 2002; Kotanen and Jefferies 1997; Iacobelli and Jefferies 1991). This prevented a recovery of the vegetation because of limited re-establishment of plants (Srivastava and Jefferies 1996; Handa et al. 2002). However, in all these studies, geese switched to alternative forage as preferred food plants became depleted leading to improved feeding conditions in one area (Alaskan arctic) and deteriorated in the other (Canadian subarctic).

In the present study, when grazing pressure was experimentally increased, foraging conditions deteriorated (in terms of MEIR) during subsequent years when grazing pressure exceeded natural recorded levels. The grazing pressure at which minimal energy requirements were met (during the first grazing in July), decreased during successive years, indicating that the vegetation did not fully recover from grazing in the previous year to the extent that similar feeding conditions were met. Although, we tested only for linear relationships between grazing pressure and MEIR, the available data do not exclude that threshold response in the effect of grazing on MEIR may occur. In that case, foraging conditions may quickly deteriorate above a threshold of grazing pressure. Deteriorating foraging conditions were most pronounced in the mesic tundra, likely as a result of the lower plant productivity (Cooper et al. 2006; Sjögersten et al. 2008). Here, after the first year of grazing geese in general could not meet their daily energy requirements at any level of grazing pressure. Even at the lowest levels of experimental grazing, which are in the range of natural recorded levels, no improvements were observed during subsequent years of grazing. This indicated that foraging conditions will not be improved by increased production by extra nutrient input via droppings as has been observed elsewhere (Bazely and Jefferies 1989; Hik and Jefferies 1990). Detailed measurements of above-ground plant productivity during the first year of the present study illustrated that experimental grazing stimulated growth rates of the graminoid Alopecurus borealis in the mesic habitat, whereas the dominant graminoid Dupontia fisheri in the wet tundra was not affected by grazing (Cooper et al. 2006). However, plant response did not show a regrowth to match or exceed ungrazed plants and reductions in plant size were still evident 2-3 weeks after the time of grazing (Cooper et al. 2006). The present study also suggests that during successive years, potential positive plant responses are insufficient to match the foraging conditions to those that the geese encountered during the first year of the study. This lack of positive response in plant growth, especially in the wet tundra, may be related to the absorption of nutrients by mosses, which prevents further access of nutrients by vascular plants (Gauthier et al. 1995; Kotanen 2002).

In contrast to natural patterns of goose grazing, we carried out two bouts of experimental grazing in both habitats with an interval of 28 days. At intensively grazed vegetation near goose breeding colonies, geese are continuously present and graze most emerging grass shoots throughout the vegetative season (D.P.J. Kuijper, personal observations). We believe that the two bouts of experimental grazing, which allowed for regrowth of the plants in the period in between, are less deleterious for grazed plants than that of continuous grazing by wild geese. The recovery phase would allow for more potential positive effects to occur following grazing.

What may be the consequences of decreasing diet quality? Nitrogen demands of adult geese are especially high in the prelaying period, and geese rely for a large part on exogenous nitrogen inputs (Choinière and Gauthier 1995; Gauthier et al. 2003; Schmutz et al. 2006). Diets containing sufficient amounts of metabolisable energy are important at the end of the breeding season to allow 
premigratory fat deposition (Sedinger and Raveling 1984). Depletion of high-quality food plants is expected to affect gosling growth (see Gadallah and Jefferies 1995a, b). Due to their smaller digestive capacity, they are more rapidly limited by food intake than adults, which increases the importance of high dietary nutrient concentrations (Sedinger and Raveling 1984). Decreasing dietary quality of goslings may directly lead to fitness consequences, as growth conditions during the early life stages of goslings determine life history traits (Sedinger et al. 1995b). Hence, declining diet quality, both in terms of nitrogen and $\mathrm{ME}$ content, are predicted to affect different stages of the life cycle of geese but both may lead to important fitness consequences. A reduced diet quality and metabolisable energy IR in relation to increased grazing pressure, therefore, represents a likely mechanism for density-dependent feedbacks at the population level.

Increasing barnacle goose numbers and limits in exploitation?

The Svalbard barnacle goose population has been increasing since 1948 (Owen and Black 2005) and despite decreasing productivity (numbers of juveniles per adult), the overall population has continued to grow with 5\% annually (Jefferies and Drent 2006). Do feedbacks via deteriorating foraging conditions with increasing grazing pressure set a limit to the exploitation of habitats by the growing numbers of barnacle geese on Svalbard?

Several studies on Svalbard illustrated that densitydependent effects on population growth do occur in different breeding colonies (Loonen et al. 1997; Drent et al. 1998; Black et al. 1998). The observed decline in gosling growth rate and adult body size in relation to the age of different breeding colonies suggest a local saturation of habitats (Black et al. 1998). Despite the deteriorating foraging conditions, most geese return each year to the same breeding colony because they show high faithfulness to brood rearing areas (Cooch et al. 1993; Lindberg and Sedinger 1998; Loonen et al. 1997). However, feedback mechanisms operating via the vegetation seem to prevent an unlimited increase of numbers at a local scale (see Drent et al. 1998). By moving to new areas, geese may escape from these density-dependent effects operating at a local scale (Jefferies and Drent 2006). Geese can leave to colonise new unexploited areas or settle at the periphery of an existing colony (Ganter and Cooke 1998; Lindberg and Sedinger 1998). These alternative breeding areas may provide better foraging conditions leading to increased growth rate and first year survival rate of goslings in these unexploited habitats (Cooch et al. 1993). Also on Svalbard, local return rates of female goslings and adults to their natal breeding colony have decreased in some colonies (Loonen et al. 1997). The continuous growth of the total Svalbard barnacle population has, therefore, mainly been attributed to the continuous colonisation of new breeding areas (Black 1998; Jefferies and Drent 2006). Additionally, global warming is predicted to lead to a substantial increase in the range of suitable habitats, which are currently unsuitable for arctic geese (Jensen et al. 2008). An increase in primary productivity of the vegetation as a result of this warming could increase the carrying capacity of already intensively goose-grazed areas and could release the population (temporarily) from density-dependent regulation.

These patterns in combination with the findings of the present study suggest that at a local scale (breeding colony) vegetation changes, as a result of continuous goose grazing, explain density-dependent effects on local population size. However, they do not seem to limit the overall population size as the amount of suitable breeding habitat currently does not limit a further increase in goose numbers.

Acknowledgments Funding for the FRAGILE project came from the European Union, project number EVK2-2001-00235. The fieldwork in Kongsfjorden was supported by the Netherlands Polar Programme and the Netherlands Arctic Station. Permission for using wild Barnacle geese in the experiments was provided by the Gorvernor of Svalbard. The animal experiments were conducted with the approval of the Norwegian animal health authority. We thank the University Centre on Svalbard (UNIS) for providing safety training and logistics for the fieldwork. Our special thanks go to Laura Hondshorst, Theresa Walther and Suzanne Lubbe, who greatly helped with carrying out the field work in 2003 and 2004, respectively. We would like to thank Rudi Drent, René van der Wal and Elisabeth Cooper for their useful comments on the manuscript. The work of the first author during writing of the manuscript has been supported by a Marie Curie Transfer of Knowledge Fellowship BIORESC of European Community's Sixth Framework Programme under contract number MTKDCT-2005-029957.

Open Access This article is distributed under the terms of the Creative Commons Attribution Noncommercial License which permits any noncommercial use, distribution, and reproduction in any medium, provided the original author(s) and source are credited.

\section{References}

Alipayo D, Valdez R, Holechek JL, Cardenas M (1992) Evaluation of microhistological analysis for determining ruminant diet botanical composition. J Ran Manage 45:148-152

Bazely DR, Jefferies RL (1989) Leaf and shoot demography of an arctic stoloniferous grass, Puccinellia-Phryganodes, in response to grazing. J Ecol 77:811-822

Black JM (1998) Movement of barnacle geese between colonies in Svalbard and the colonisation process. Nor Polarinst Skr 200:115-128

Black JM, Cooch EG, Loonen MJJE, Drent RH, Owen M (1998) Body size variation in barnacle goose colonies: evidence for local saturation of habitats. Nor Polarinst Skr 200:129-140 
Cargill SM, Jefferies RL (1984) The effects of grazing by lesser snow geese on the vegetation of a sub-arctic salt-marsh. J Appl Ecol 21:669-686

Choinière L, Gauthier G (1995) Energetics of reproduction in female and male greater snow geese. Oecologia 103:379-389

Cooch EG, Jefferies RL, Rockwell RF, Cooke F (1993) Environmental change and the cost of philopatry-an example in the lesser snow goose. Oecologia 93:128-138

Cooper EJ, Jónsdóttir IS, Pahud A (2006) Grazing by captive barnacle geese affects graminoid growth and productivity on Svalbard. Mem Natl Inst Polar Res Spec Issue 59:1-15

Drent RH, Black JM, Loonen MJJE, Prop J (1998) Barnacle geese Branta leucopsis on Nordenskioldkysten, western Spitsbergenthirty years from colonisation to saturation. Nor Polarinst Skr 200:105-114

Ebbinge BW, Canters K, Drent RH (1975) Foraging routines and estimated daily food intake in Barnacle geese wintering in the northern Netherlands. Wildfowl 26:5-19

Eerden MR (1998) Patchwork: patch use, habitat exploitation and carrying capacity for water birds in Dutch freshwater. Dissertation, University of Groningen

Esselink P, Helder-Guideo JF, Aerts BA, Gerdes K (1997) The impact of grubbing by Greylag geese (Anser anser) on the vegetation dynamics of a tidal marsh. Aquat Bot 55:261-279

Fox AD, Madsen J, Boyd H, Kuijken E, Norriss DW, Tombre IM, Stroud DA (2005) Effects of agricultural change on abundance, fitness components and distribution of two arctic-nesting goose populations. Glob Ch Biol 11:881-893

Gadallah FL, Jefferies RL (1995a) Comparison of the nutrient content of the principal forage plants utilized by lesser snow geese on summer breeding grounds. J Appl Ecol 32:263-275

Gadallah FL, Jefferies RL (1995b) Forage quality in brood rearing areas of the lesser snow goose and the growth of captive goslings. J Appl Ecol 32:276-287

Ganter B, Cooke F (1998) Colonial nesters in a deteriorating habitat: Site fidelity and colony dynamics of lesser snow geese. Auk 115:642-652

Gauthier G, Hughes RJ, Reed A, Beaulieu J, Rochefort L (1995) Effect of grazing by greater snow geese on the production of graminoids at an arctic site (Bylot island, NWT, Canada). J Appl Ecol 83:653-664

Gauthier G, Bety J, Hobson KA (2003) Are greater snow geese capital breeders? New evidence from a stable-isotope model. Ecology 84:3250-3264

Gebzynska Z, Myrcha A (1966) The method of quantitative determining of the food composition of rodents. Acta Theriologica 11:385-390

Goering HK, Van Soest PJ (1970) Forage fiber analyses (apparatus, reagents, procedures, and some applications). Agricultural Handbook No.379. ARS, USDA, Washington, DC

Handa IT, Harmsen R, Jefferies RL (2002) Patterns of vegetation change and the recovery potential of degraded areas in a coastal marsh system of the Hudson Bay lowlands. J Ecol 90:86-99

Hik DS, Jefferies RL (1990) Increase in the net aboveground primary production of a salt-marsh forage grass- a test of the predictions of the herbivores-optimization model. J Ecol 78:180-195

Huisman J, Olff H, Fresco LFM (1993) A hierarchical set of models for species response analysis. J Veg Sci 4:37-46

Iacobelli A, Jefferies RL (1991) Inverse salinity gradients in coastal marshes and the death of stands of Salix: the effects of goose foraging. J Ecol 79:61-73

Jefferies RL, Drent RH (2006) Arctic geese, migratory connectivity and agricultural change: calling the sorcerer's apprentice to order. Ardea 94:537-554

Jefferies RL, Rockwell RF (2002) Foraging geese, vegetation loss and soil degradation in an Arctic salt marsh. Appl Veg Sci 5:7-16
Jefferies RL, Rockwell RF, Abraham KE (2004) Agricultural food subsidies, migratory connectivity and large-scale disturbance in arctic coastal systems: a case study. Integr Comp Biol 44:130 139

Jefferies RL, Jano AP, Abraham KF (2006) A biotic agent promotes large-scale catastrophic change in the coastal marshes of Hudson Bay. J Ecol 94:234-242

Jensen RA, Madsen J, O'Connell M, Wisz MS, Tømmervik H, Mehlum F (2008) Prediction of the nesting distribution of pinkfooted geese (Anser brachyrhynchus) in Svalbard under a warmer climate scenario. Global Change Biology 14:1-10

Karasov WH (1990) Digestion in birds: chemical and physiological determinants and ecological implications. Stud Avian Biol 13:391-415

Kotanen PM (2002) Fates of added nitrogen in freshwater arctic wetlands grazed by snow geese: the role of mosses. Arct Antarct Alp Res 34:219-225

Kotanen PM, Jefferies RL (1997) Long-term destruction of sub-arctic wetland vegetation by lesser snow geese. Ecoscience 4:179-182

Kuijper DPJ, Bakker JP, Cooper EJ, Ubels R, Jónsdóttir IS, Loonen MJJE (2006) Intensive grazing by barnacle geese depletes arctic seed bank. Can J Bot 84:995-1004

Lindberg MS, Sedinger JS (1998) Ecological significance of broodsite fidelity in black brant: spatial, annual, and age-related variation. Auk 115:436-446

Loonen MJJE, Solheim B (1998) Does arctic vegetation change when grazed by barnacle geese? Nor Polarinst Skr 200:99-104

Loonen MJJE, Oosterbeek K, Drent RH (1997) Variation in growth of young and adult size in barnacle geese Branta leucopsis: evidence for density dependence. Ardea 85:177-192

Loonen MJJE, Tombre IM, Mehlum F (1998) Development of an arctic barnacle goose colony: interactions between density and predation. Nor Polarinst Skr 200:67-80

McNaughton SJ (1984) Grazing lawns: animals in herds, plant form, and coevolution. Am Nat 124:863-886

Nolet BA, Butler PJ, Masman D, Woakes AJ (1992) Estimation of daily energy expenditure from heart rate and doubly labeled water in exercising geese. Physiol Zool 65:1188-1216

Owen M (1975) Assessment of fecal analysis technique in waterfowl studies. J Wildl Manage 39:271-279

Owen M, Black JM (2005) Barnacle goose Branta leucopsis. In: Kear J (ed) Ducks, geese and swans, vol I. Oxford University Press, Oxford, pp 329-334

Owen M, Wells RL, Black JM (1992) Energy budgets of wintering barnacle geese: the effects of declining food resources. Ornis Scand 23:451-458

Person BT, Babcock CA, Ruess RW (1998) Forage variation in brood-rearing areas by pacific black brant geese on the YukonKuskokwim delta, Alaska. J Ecol 86:243-259

Person BT, Herzog MP, Ruess RW, Sedinger JS, Athony RM, Babcock CA (2003) Feedback dynamics of grazing lawns: coupling vegetation change with animal growth. Oecologia 135:583-592

Prop J, Black JM (1998) Food intake, body reserves and reproductive success of barnacle geese Brantra leucopsis staging in different habitats. Nor Polarinst Skr 200:177-194

Prop J, de Vries J (1993) Impact of snow and food conditions on the reproductive performance of barnacle geese Branta leucopsis. Ornis Scand 24:110-120

Prop J, Vulink T (1992) Digestion by Barnacle geese in the annual cycle: the interplay between retention time and food quality. Funct Ecol 6:180-189

Prop J, van Eerden MR, Drent RH (1984) Reproductive success of the branacle goose Branta leucopsis in relation to food exploitation on the breeding grounds, western Spitsbergen. Nor Polarinst Skr 181:87-117 
Rowcliffe JM, Watkinson AR, Sutherland WJ, Vickery JA (2001) The depletion of algal beds by geese: a predictive model and test. Oecologia 127:361-371

Schmutz JA, Hobson KA, Morse JA (2006) An isotopic assessment of protein from diet and endogenous stores: effects on egg production and incubation behaviour of geese. Ardea 94:385397 Special issue

Seber GAF, Pemberton JR (1979) The line intercept method for studying plant cuticles from rumen and fecal samples. J Wildl Manage 43:916-925

Sedinger JS, Raveling DG (1984) Dietary selectivity in relation to availability and quality of food for goslings of cackling geese. Auk 101:295-306

Sedinger JS, White RG, Hupp J (1995a) Metabolizability and partitioning of energy and protein in green plants by yearling lesser snow geese. Condor 97:116-122

Sedinger JS, Flint PL, Lindberg MS (1995b) Environmental influence on life history traits-growth, survival, and fecundity in black brant (Branta bernicla). Ecology 76:2404-2414

Sjögersten S, van der Wal R, Woodin SJ (2008) Habitat type determines herbivory controls over $\mathrm{CO}_{2}$ fluxes in a warmer Arctic. Ecology 89:2103-2116

Srivastava DS, Jefferies RL (1996) A positive feedback: herbivory, plant growth and goose herbivory in an arctic coastal ecosystem. J Ecol 84:31-42
Stahl J, Loonen MJJE (1998) Effects of predation risk on site selection of barnacle geese during brood-rearing. Nor Polarinst Skr 200:67-79

Van Soest PJ (1982) Nutritional ecology of the ruminant. O and B Books, Corvallis

Vickery JA, Sutherland WJ, Watkinson AR, Lane SJ, Rowcliffe JM (1995) Habitat switching by dark-bellied Brent geese Branta-bbernicla (L.) in relation to food depletion. Oecologia 103:499508

Wegener C, Odasz-Albrigtsen AM (1998) Do Svalbard reindeer regulate standing crop in the absence of predators? A test of the "exploitation ecosystems model". Oecologia 116:202-206

Williams TD, Cooch EG, Jefferies RL, Cooke F (2005) Environmental degradation, food limitation and reproductive outputjuvenile survival of lesser snow geese. J Anim Ecol 62:766-777

Wisz MS, Tamstorf MP, Madsen J, Jespersen M (2008) Where might the western Svalbard tundra be vulnerable to pink-footed goose (Anser brachyrhynchus) population expansion? Clues from species distribution models. Divers Distrib 14:26-37

Zacheis A, Hupp JW, Ruess RW (2001) Effects of migratory geese on plant communities of an Alaskan salt marsh. J Ecol 89:57-71

Zar JH (1984) Biostatistical analysis. Prentice Hall, UK

Zellmer ID, Clauss MJ, Hik DS, Jefferies RL (1993) Growth responses of arctic graminoids following grazing by captive lesser snow geese. Oecologia 93:487-492 